\section{Chapter \\ [4]}

\title{
An overview on environmental pollution caused by heavy metals released from e-waste and their bioleaching
}

\author{
Deepak Pant ${ }^{1}$ and Varun Dhiman ${ }^{2, *}$ \\ ${ }^{1}$ School of Chemical Sciences, Central University of Haryana, \\ Jant-Pali, Mahendergarh, Haryana 123031, India \\ ${ }^{2}$ Waste Management Laboratory, School of Earth and Environmental Sciences, \\ Central University of Himachal Pradesh, Shahpur 176206, Himachal Pradesh, India
}

\begin{abstract}
The consistently expanding quantum of e-waste is booming at an extremely high pace which is around 20-25 Mt for every year. The metal recovery from e-waste is a developing zone of scientific enthusiasm because of quality of wide scope of valuable metals present in it. Bioleaching can improve and recover the heterogenic metals present in electronic waste in a proficient way, thereby helps in its effective management. The microbial strains involved in metals bioleaching mobilize the metals under the influence of cyanide and acidic medium. Acidithiobacillus thiooxidans, Thiobacillus ferrooxidans, Thermoplasma acidophilum, Chromobacterium violaceum, Acidithiobacillus and Aspergillus niger are the major microbial strains engaged with metals bioleaching. This chapter emphasized on the types of microorganisms and their performance in metal bioleaching and inspects the bioleaching of gold, iron and copper from e-waste scrap. Additionally, the key environmental and health concerns associated with e-waste exposure are also discussed. Therefore, this chapter provides comprehensive information on eco-friendly and efficient bioleaching of heavy metals from environment.
\end{abstract}

Keywords

Bioleaching, Electronic waste, Heavy metal recovery, Waste management

27 Varun Dhiman, Email: varundhiman79@gmail.com ( ${ }^{*}$ Corresponding author)

(c) 2020 | Agro Environ Media I Agriculture and Environmental Science Academy, Haridwar, India 
Abbreviations: MoEFCC: Ministry of Environment, Forest and Climate change, EEE: Electrical and electronic equipment's, e-waste: Electronic waste, HF: Hydrofluoric acid, GEWM: Global e-waste monitor, Mt: metric tons, PCBs: Poly Chlorinated Biphenyls, BFR: Brominated flame retardants, PDA: Potato dextrose agar, $\mathrm{SF}_{6}$ : Sulphur hexafluoride, ICP-OES: Inductively coupled plasma-optical emission spectrometry, CRTs: Cathode ray tubes.

E-waste definition: According to e-waste (management) rules, 2016 " $e$-waste' means electrical and electronic equipment, whole or in part discarded as waste by the consumer or bulk consumer as well as rejects from manufacturing, refurbishment, and repair processes".

\section{Introduction}

Electrical and electronic equipment (EEE) constitute a major proportion of e-waste (Ghosh et al., 2020). These appliances have become an integral part of human life as a symbol of extravagance and a higher standard of living. Most recent turns of events and innovative upgradations in the technology decrease the expense of electric and electronic equipment prompt their higher utilization, and in this manner extending the electronic market at a higher rate (Pavithra et al., 2020). Notwithstanding, the assortment and recycling of electronic waste happen at a moderate pace when contrasted with its production which thus causes natural concerns (Awasthi et al., 2016). e-waste is a worldwide ecological issue that especially influences the natural ecosystem through its harmful synthetic substances that leached out in the distinctive natural environmental spheres in small fractions and hence initiate toxic impacts in the earth's ecosystems (Vaish et al., 2020). Scientific management of e-waste is kept on being a test in the present situation. In this manner to handle the persevering issue, different physical and chemical modes have been adopted (Kaya, 2016). Since these advancements are profoundly proficient for e-waste management and source recuperation, they are known for their higher energy utilization and operational expense. Despite these, bioleaching offers a characteristic, natural, and cost-benefit organic methodology for e-waste management and recuperation of valuable metals present in it using a variety of bacterial and fungal species. The bioleaching productively oversees electronic waste and recoup valuable metals present in e-waste scrap with minimal ecological harms.

This chapter emphasized the types of microorganisms and their performance in metal bioleaching and inspects the bioleaching of gold, iron, and copper from e-waste scrap. Additionally, health and environmental impacts are also discussed.

\section{Statics on e-waste generation}

The consistently expanding quantum of e-waste is booming at an extremely high pace which is around 20-25 Mt for every year (Mihai, 2016). As indicated by the GEWM report (2020), the absolute e-waste 
generated in 2019 is assessed to be 53.6 million metric tons over the globe which was configured to 7.3 $\mathrm{kg}$ per capita generation. The scientists anticipated that the absolute e-waste will ascend to $74 \mathrm{Mt}$ in 2030. Aside from generation, the documented collection and recycling of e-waste was found to be 9.3 Mt which was merely a total fraction of $17.4 \%$ when compared to the total waste generated (Forti et al., 2020). The amount of e-waste in the year 2019 involved various Categories as appeared in Table 1. In the case of Asia, this report gauges $24.9 \mathrm{Mt}$ (5.6 kg per capita) generation of e-waste while just $11.7 \%$ of it is appropriately collected and recycled (Forti et al., 2020).

\section{Bioleaching pathways}

Bioleaching includes biochemical systems of bacterial and fungal strains for proficient metal recuperation from e-waste. The procedure utilizes their metabolic byproducts and enzymatic activities. There are two fundamental modes of bioleaching pathways as described below:

\section{Direct}

This pathway includes the process of metal oxidation with the assistance of enzymatic responses started by explicit microorganisms (Bal et al., 2019; Zhao and Wang, 2019). In this procedure, the electronic waste is presented at the inoculation stage by the addition of metabolic acids in a single stage and two-way stages (Arya and Kumar, 2020; Baniasadi et al., 2020). For instance, certain microbes like Thiobacillus ferrooxidans, which are profoundly acidophilic and gram-negative aides in the oxidation of $\mathrm{Fe}^{2+}$ to $\mathrm{Fe}^{3+}$ and in this way acquired vitality for their metabolic capacities (Miao et al., 2017). Reactions are delineated below:

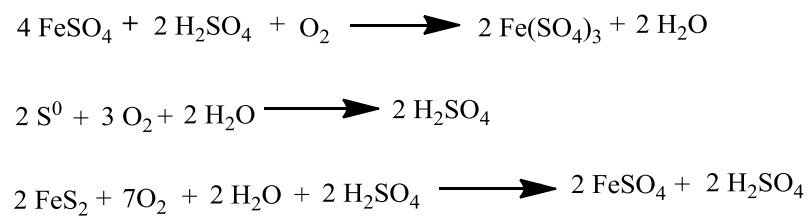

Table 1. Different categories of equipment's that produces e-waste (Forti et al., 2020).

\begin{tabular}{ll}
\hline Categories of equipment's & Quantity (Mt) \\
\hline Smaller equipment's & 17.4 \\
Large electronic equipment & 13.1 \\
Electronic temperature exchange equipment & 10.8 \\
Monitors and Screens & 6.7 \\
IT and telecommunication equipment's & 4.7 \\
Lamps, bulbs & 0.9 \\
\hline
\end{tabular}




\section{Indirect}

This pathway is a two-way process where microorganisms don't legitimately include in the mineralization of metals yet they generate solid oxidizing agents. For example, ferric ions and sulfuric acid that cooperate with metals and balance out them in a profoundly acidic medium. The oxidation of $\mathrm{Fe}, \mathrm{S}$, and distinctive metal sulfides assumes their significant role in keeping up acidic conditions fundamental for mental disintegration (Sajjad et al., 2019; Sand, Gehrke et al., 2001). The mechanism of copper bioleaching is represented in Figure 1. Bioleaching includes the use of biological agents for e-waste metal recovery. They transform the metals present in the electronic waste scrap (Pant et al., 2018). The biochemistry involved in bioleaching is presented in Table 2.
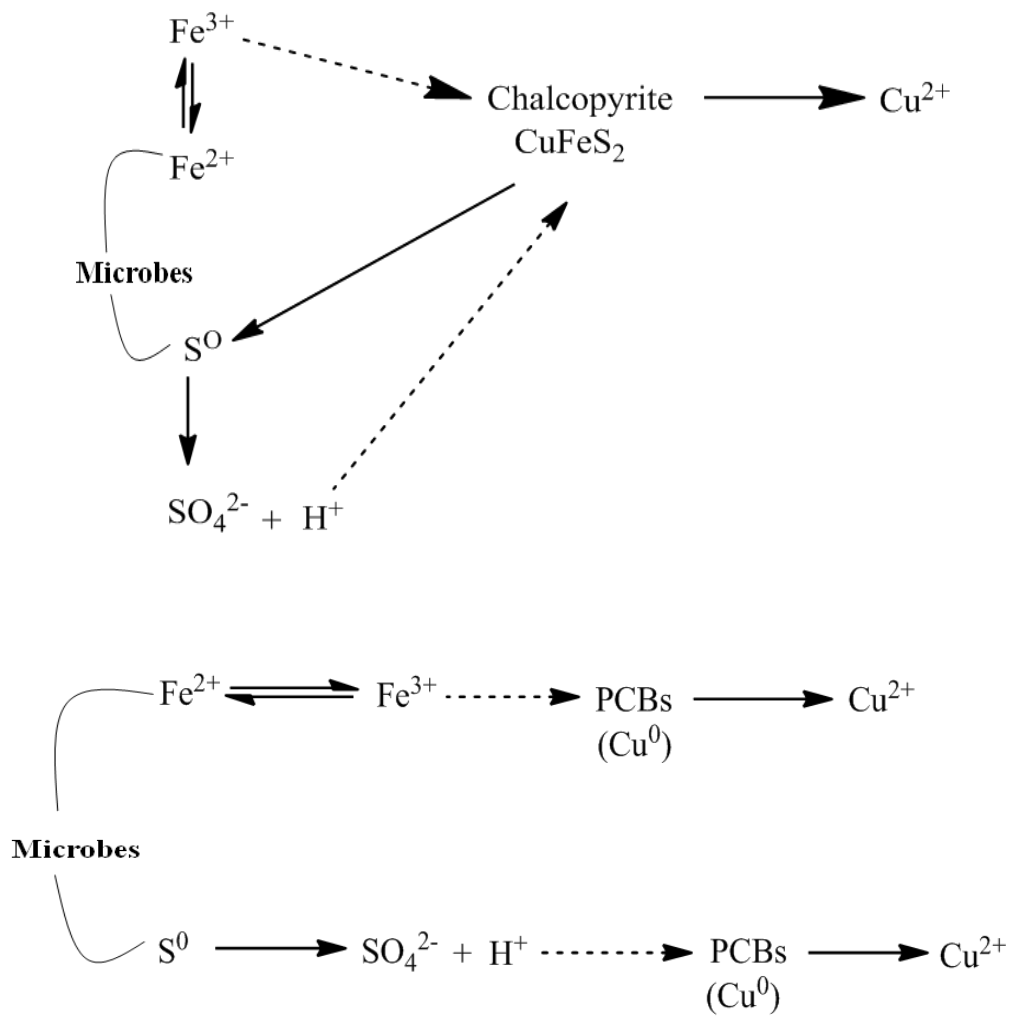

Figure 1. Indirect bioleaching pathway of copper bioleaching from chalcopyrite and PCBs (Source: Zhao and Wang, 2019). 
Table 2. Biochemistry involved in biological leaching of various metal ions.

\begin{tabular}{|c|c|c|c|c|}
\hline Reagents & $\begin{array}{l}\text { Leached } \\
\text { metals }\end{array}$ & $\begin{array}{l}\text { Microbes } \\
\text { involved }\end{array}$ & Biochemistry & References \\
\hline $\begin{array}{l}\mathrm{HCl}, \\
\mathrm{HNO}_{3}, \\
\mathrm{H}_{2} \mathrm{SO}_{4}, \\
\text { Aqua regia }\end{array}$ & $\mathrm{Co}, \mathrm{Li}$ & $\begin{array}{l}\text { Aspergillus niger, } \\
\text { Acidithiobacillus } \\
\text { thiooxidans }\end{array}$ & $\begin{array}{l}\mathrm{Co}^{2+}+\mathrm{Na}_{2} \mathrm{~S} \rightarrow \mathrm{CoS}{ }_{(s)}+2 \mathrm{Na}^{+}(\mathrm{aq}) \\
\mathrm{Co}^{2+}{ }_{(\mathrm{aq})}+2 \mathrm{NaOH} \rightarrow \mathrm{Co}(\mathrm{OH})_{2(\mathrm{~s})}+2 \mathrm{Na}^{+} \\
\mathrm{Co}^{2+}{ }_{(\mathrm{aq})}+\mathrm{Na}_{2} \mathrm{C}_{2} \mathrm{O}_{4}+2 \mathrm{H}_{2} \mathrm{O} \rightarrow \mathrm{CoC}_{2} \mathrm{O}_{4} .2 \mathrm{H}_{2} \mathrm{O}_{(\mathrm{s})} \\
+2 \mathrm{Na}^{+}{ }_{(\mathrm{aq})} \\
2 \mathrm{Li}^{+}{ }_{(\mathrm{aq})}+\mathrm{Na}_{2} \mathrm{CO}_{3} \rightarrow \mathrm{Li}_{2} \mathrm{CO}_{3(\mathrm{~s})}+2 \mathrm{Na}^{+}{ }_{(\mathrm{aq})}\end{array}$ & $\begin{array}{l}\text { Biswal } \\
\text { et al. (2018) }\end{array}$ \\
\hline $\begin{array}{l}\text { Aqua } \\
\text { regia, } \\
\text { Concen- } \\
\text { trated HF }\end{array}$ & $\begin{array}{l}\mathrm{Mn}, \mathrm{Al}, \\
\mathrm{Zn}, \mathrm{Cu}, \\
\mathrm{Ti}\end{array}$ & $\begin{array}{l}\text { Thiobacillus } \\
\text { ferrooxidans }\end{array}$ & $\begin{array}{l}\mathrm{ZnS}+2 \mathrm{Fe}^{3+} \rightarrow \mathrm{Zn}^{2+}+2 \mathrm{Fe}^{2+}+\mathrm{S}^{0} \\
\mathrm{ZnS}+2 \mathrm{O}_{2} \rightarrow \mathrm{Zn}^{2+}+\mathrm{SO}_{4}^{2-} \\
4 \mathrm{Fe}^{2+}+\mathrm{O}_{2}+4 \mathrm{H}^{+} \rightarrow 4 \mathrm{Fe}^{3+}+2 \mathrm{H}_{2} \mathrm{O}\end{array}$ & $\begin{array}{l}\text { Arshadi } \\
\text { et al. }(2020)\end{array}$ \\
\hline $\begin{array}{l}\mathrm{KCl} \\
\mathrm{K}_{2} \mathrm{HPO}_{4} \\
\left(\mathrm{NH}_{4}\right)_{2} \mathrm{SO}_{4}\end{array}$ & $\mathrm{Fe}$ & $\begin{array}{l}\text { Thermophilic } \\
\text { culture }\end{array}$ & $\begin{array}{l}\mathrm{Fe}_{7} \mathrm{~S}_{8}+7 \mathrm{FeSO}_{4} \rightarrow 7 \mathrm{FeSO}_{4}+7 \mathrm{H}_{2} \mathrm{~S}+\mathrm{S} \\
\mathrm{Fe}_{7} \mathrm{~S}_{8}+\mathrm{H}_{2} \mathrm{O}+15_{5} \mathrm{O}_{2}(\mathrm{~g}) \rightarrow 7 \mathrm{FeSO}_{4}+\mathrm{H}_{2} \mathrm{SO}_{4} \\
\mathrm{Fe}_{7} \mathrm{~S}_{8}+\mathrm{O}_{2}(\mathrm{~g}) \rightarrow 7 \mathrm{FeSO}_{4}+\mathrm{S} \\
\mathrm{Fe}_{7} \mathrm{~S}_{8}+31 \mathrm{Fe}_{2}\left(\mathrm{SO}_{4}\right)_{3}+32 \mathrm{H}_{2} \mathrm{O} \rightarrow 69 \mathrm{Fe}\left(\mathrm{SO}_{4}\right) \\
+32 \mathrm{H}_{2} \mathrm{SO}_{4} \\
\mathrm{Fe}_{7} \mathrm{~S}_{8}+7 \mathrm{Fe}_{2}\left(\mathrm{SO}_{4}\right)_{3} \rightarrow 21 \mathrm{FeSO}_{4}+8 \mathrm{~S}^{0}\end{array}$ & $\begin{array}{l}\text { Altinkaya } \\
\text { et al. (2018) }\end{array}$ \\
\hline $\begin{array}{l}\text { Inorganic } \\
\text { Sulfuric } \\
\text { acid }\end{array}$ & $\mathrm{Cu}$ & $\begin{array}{l}\text { Acidithiobacillus } \\
\text { thiooxidans }\end{array}$ & $\begin{array}{l}\mathrm{S}^{0}+1.5 \mathrm{O}_{2}+\mathrm{H}_{2} \mathrm{O} \rightarrow 2 \mathrm{H}^{+}+\mathrm{SO}_{4} 4^{--} \\
\mathrm{Cu} \rightarrow \mathrm{Cu}^{+}+\mathrm{e}^{-} \\
\mathrm{Cu}^{+} \rightarrow \mathrm{Cu}^{2+}+\mathrm{e}^{-} \\
\mathrm{O}_{2}+4 \mathrm{H}^{+}+4 \mathrm{e}^{-} \rightarrow 2 \mathrm{H}_{2} \mathrm{O} \\
2 \mathrm{Cu}^{+}+\mathrm{O}_{2}+4 \mathrm{H}^{+} \rightarrow 4 \mathrm{Cu}^{2+}+2 \mathrm{H}_{2} \mathrm{O} \\
\mathrm{Cu}^{2+}+\mathrm{SO}_{4} 4^{2-} \rightarrow \mathrm{CuSO}_{4}\end{array}$ & $\begin{array}{l}\text { Hong and } \\
\text { Vali (2014) }\end{array}$ \\
\hline $\begin{array}{l}\text { Sulfuric } \\
\text { acid }\end{array}$ & $\begin{array}{l}\mathrm{Cu}, \mathrm{Al}, \\
\mathrm{Zn}, \mathrm{Ni}\end{array}$ & $\begin{array}{l}\text { Thermoplasma } \\
\text { acidophilum }\end{array}$ & $\begin{array}{l}\mathrm{Cu}^{0}+\mathrm{Fe}_{2}\left(\mathrm{SO}_{4}\right)_{3} \rightarrow \mathrm{CuSO}_{4}+2 \mathrm{FeSO}_{4} \\
\mathrm{Zn}^{0}+\mathrm{Fe}_{2}\left(\mathrm{SO}_{4}\right)_{3} \rightarrow \mathrm{ZnSO}_{4}+2 \mathrm{FeSO}_{4} \\
\mathrm{Ni}^{0}+\mathrm{Fe}_{2}\left(\mathrm{SO}_{4}\right)_{3} \rightarrow \mathrm{NiSO}_{4}+2 \mathrm{FeSO}_{4} \\
2 \mathrm{Al}^{0}+3 \mathrm{Fe}_{2}\left(\mathrm{SO}_{4}\right)_{3} \rightarrow \mathrm{Al}_{2}\left(\mathrm{SO}_{4}\right)_{3}+6 \mathrm{FeSO}_{4}\end{array}$ & $\begin{array}{l}\text { Ilyas } \\
\text { et al. (2007) }\end{array}$ \\
\hline Cyanide & $\mathrm{Au}$ & $\begin{array}{l}\text { Chromobacterium } \\
\text { violaceum }\end{array}$ & 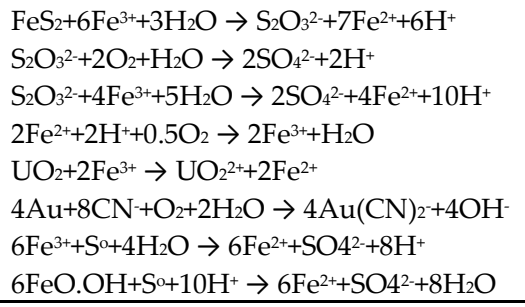 & $\begin{array}{l}\text { Nancharai- } \\
\text { ah et al. } \\
(2016)\end{array}$ \\
\hline
\end{tabular}

\section{Mechanisms of metals bioleaching}

\section{Gold bioleaching}

Gold bioleaching gives a significant and alluring exploration research area including innovative progression in gold recovery from electronic waste. The mesophilic, facultative, and gram-negative microbe Chromobacterium violaceum (Pant and Sharma, 2015) gives a chance to recoup the gold from 
printed circuit boards of the waste gadgets ( $\mathrm{Li}$ et al., Ma, 2015). This specific microorganism generates $\mathrm{CN}^{-}$that may help in gold solubilization in the acidic medium in this way helps in gold bioleaching in an effective manner (Chi et al., 2011). The mechanism of gold bioleaching (Liu et al., 2016) is summarized in the following chemical reactions:

$$
\begin{aligned}
& 4 \mathrm{Au}+8 \mathrm{CN}^{-} \longrightarrow 4 \mathrm{Au}(\mathrm{CN})_{2}^{-}+4 \mathrm{e}^{-} \\
& \mathrm{O}_{2}+2 \mathrm{H}_{2} \mathrm{O}+4 \mathrm{e}^{-} \longrightarrow 4 \mathrm{OH}^{-} \\
& 4 \mathrm{Au}+8 \mathrm{CN}^{-}+\mathrm{O}_{2}+2 \mathrm{H}_{2} \mathrm{O} \stackrel{\text { Chromobacterium violaceum }}{\longrightarrow} 4 \mathrm{Au}(\mathrm{CN})_{2}^{-}+4 \mathrm{OH}^{-}
\end{aligned}
$$

Various investigations have been done on in a similar field to get upgraded recuperation rates of gold (Willner and Fornalczyk, 2013). Aside from Chromobacterium violaceum, researchers also utilize Pseudomonas balearica SAEI strain for gold bioleaching and a recuperation rate of $68.5 \%$ has been observed (Kumar et al., 2018). Also, another specialist utilizes the organism Aspergillus niger of the family Trichocomaceae for gold bioleaching and $56 \%$ of the recuperation rate has been accomplished (Argumedo-Delira et al., 2019; Becci et al., 2020). The flow chart of gold bioleaching (Figure 2) using Aspergillus niger from printed circuit boards is given below:

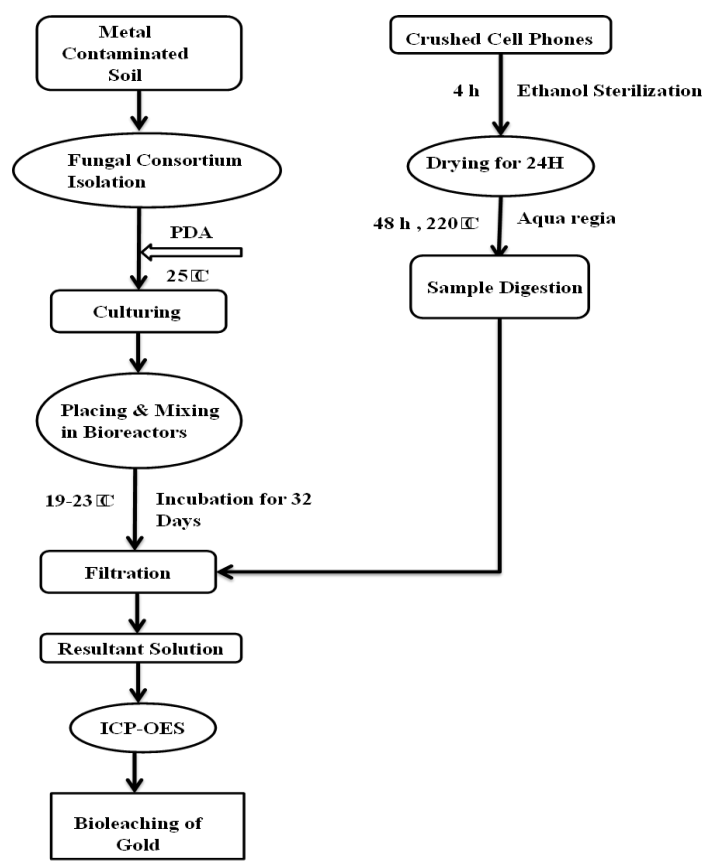

Figure 2. Gold $(\mathrm{Au})$ bioleaching from printed circuit boards of mobile phones using Aspergillus niger (Argumedo-Delira et al., 2019). 


\section{Iron bioleaching}

Iron is bleached by acidophilic microbial species including the cooperation of ferric ions with $\mathrm{H}_{2} \mathrm{SO}_{4}$ either by thiosulfate or polysulfide pathways (Figure 3) and in this way metal solubilization occurs. These bacteria can contact with iron and oxidize the $\mathrm{Fe}^{2+}$ ions to $\mathrm{Fe}^{3+}$ and reduces sulfur to $\mathrm{S}_{2} \mathrm{O}_{3}{ }^{2-}$. For example, Acidithiobacillus ferrooxidans bacteria attacks iron and initiate extracellular enzymatic actions (Maluckov, 2017; Saavedra et al., 2020). Oxidation of $\mathrm{Fe}^{3+}$ to $\mathrm{Fe}^{2+}$ ions happened due to electron transfer (Drits and Manceau, 2000). At the outer membrane of bacteria, $\mathrm{Fe}^{2+}$ ions are reoxidized to $\mathrm{Fe}^{3+}$ ions (Geerlings et al., 2019). The thiosulfate oxidation mechanism (Masau, 1999) is represented in the following generalized equations:

$$
\begin{aligned}
& \mathrm{FeS}_{2}+3.5 \mathrm{O}_{2}+\mathrm{H}_{2} \mathrm{O} \longrightarrow \mathrm{Fe}^{2+}+2 \mathrm{SO}_{4}{ }^{2-}+2 \mathrm{H}^{+} \\
& \mathrm{MeS}+2 \mathrm{Fe}^{3+}+1.5 \mathrm{O}_{2}+\mathrm{H}_{2} \mathrm{O} \longrightarrow \mathrm{Me}^{2+}+2 \mathrm{Fe}^{2+}+\mathrm{SO}_{4}{ }^{2-}+2 \mathrm{H}^{-}
\end{aligned}
$$

\section{Thiosulfate Pathway}

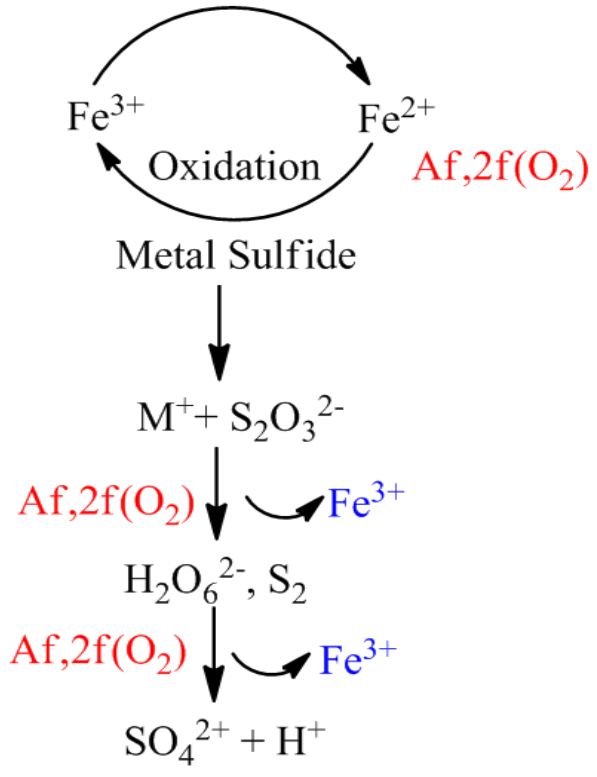

Polysulfide Pathway

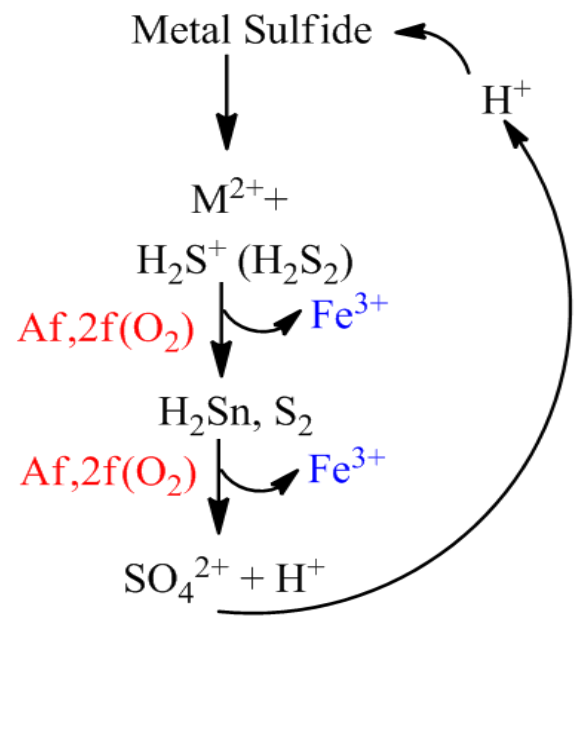

Figure 3. Mechanism of iron bioleaching involving thiosulfate or polysulfide pathways (Pant et al., 2018; Srichandan et al., 2020). 


\section{Copper bioleaching}

The copper dissolution from e-waste generally occurs in two main phases. The first phase involves the oxidation of the ferrous ion to ferric ions with the help of bacteria and the second phase involves the copper mobilization from the e-waste scrap which is induced by the ferric ion's reduction to ferrous ions. In this way, the continuous cycle between ferric and ferrous ions is going on and the copper metal is bleached from the electronic waste ( $\mathrm{Wu}$ et al., 2018). The copper bioleaching chemical reactions are given ahead:

$$
\mathrm{Fe}^{2+}+\mathrm{O}_{2}+4 \mathrm{H}^{+} \underset{\begin{array}{c}
\text { Acidithiobacillus } \\
\text { thiooxidans }
\end{array}}{\stackrel{\text { Microbes }}{\longrightarrow}} \mathrm{Fe}^{3+}+2 \mathrm{H}_{2} \mathrm{O}
$$

$$
2 \mathrm{Fe}^{3+}+\mathrm{Cu} \longrightarrow 2 \mathrm{Fe}^{2+}+\mathrm{Cu}^{2+}
$$

\section{Environmental consequences and health impacts}

A few investigations attempt to audit the toxic impacts of e-waste on people just as on various ecological environmental spheres. Investigations are referencing its natural concerns and related effects. The use of unscientific e-waste management practices like melting, roasting, open-air burning and so forth generate toxic dioxins and other air born hazardous chemicals that may have direct ecological concerns and health-related issues. Table 3 shows different environmental and health impacts that are associated with e-waste.

\begin{tabular}{|c|c|c|c|c|}
\hline E-Waste Sources & Constituents & Consequences & Health impacts & References \\
\hline $\begin{array}{l}\text { Mercury vapor } \\
\text { lamp } \\
\text { PCBs } \\
\text { Relay, Board } \\
\text { switches }\end{array}$ & $\begin{array}{l}\text { Mercury } \\
\text { vapors } \\
\text { Mercury } \\
\text { Mercury }\end{array}$ & $\begin{array}{l}\text {-Bioaccumulation causes } \\
\text { higher level of toxicity in } \\
\text { aquatic animals. e.g. fish, } \\
\text { seabirds, etc. } \\
\text {-Dry deposition in air } \\
\text { causes air pollution. } \\
\text {-Ground level interactions } \\
\text { with ozone. }\end{array}$ & $\begin{array}{l}\text {-Neuronal } \\
\text { dysfunction. } \\
\text {-Insomnia } \\
\text {-Distorted vision. } \\
\text {-Muscle weakness. } \\
\text {-Blood poisoning. } \\
\text {-Disturbed } \\
\text { sensations. } \\
\text {-memory loss. }\end{array}$ & $\begin{array}{l}\text { Ha et al. } \\
\text { (2017); Lind- } \\
\text { qvist (1995); } \\
\text { Sarikaya et } \\
\text { al. (2010); } \\
\text { Wang et al. } \\
\text { (2020); } \\
\text { Wang et al. } \\
\text { (2019) }\end{array}$ \\
\hline Housing wiring & BFR & $\begin{array}{l}\text {-Affect air quality of } \\
\text { e-waste dismantling facility. } \\
\text {-Contaminate the soil } \\
\text { through their } \\
\text { sedimentations with soil } \\
\text { particles. -Bioaccumulation } \\
\text { within the food chain. }\end{array}$ & $\begin{array}{l}\text {-Cancer. } \\
\text {-Diabetes. } \\
\text {-Neurological } \\
\text { concerns. } \\
\text {-Reproductive and } \\
\text { developmental } \\
\text { abnormalities. }\end{array}$ & $\begin{array}{l}\text { Kim et al. } \\
\text { (2014); } \\
\text { Segev et al. } \\
\text { (2009); Yu et } \\
\text { al. (2016) }\end{array}$ \\
\hline
\end{tabular}

Table 3. List of environmental and health impacts of hazardous constituents present in e-waste. 
Table 3. Continued...

\begin{tabular}{|c|c|c|c|c|}
\hline E-Waste Sources & Constituents & Consequences & Health impacts & References \\
\hline Circuit Breakers & $\mathrm{SF}_{6}$ & $\begin{array}{l}\text {-High level of global } \\
\text { warming potential as } \\
\text { compared to carbon dioxide } \\
\text { and methane. } \\
\text {-Highly persistent in nature. } \\
\text {-On its decomposition, it } \\
\text { generates highly toxic } \\
\text { Di-sulfur decafluoride. } \\
\text {-Highly persistent in nature. }\end{array}$ & $\begin{array}{l}\text {-Damaged hepatic } \\
\text { and renal organ } \\
\text { systems. } \\
\text {-Suffocation. } \\
\text {-Nasal and bronchitis } \\
\text { congestion. } \\
\text {-Extensive lung } \\
\text { damage. } \\
\text {-Respiratory } \\
\text { problems. } \\
\text {-Dizziness and } \\
\text { fainting. }\end{array}$ & $\begin{array}{l}\text { Blackburn } \\
\text { and Solu- } \\
\text { tions (2017); } \\
\text { Dervos and } \\
\text { Vassiliou } \\
\text { (2000); Tsai } \\
\text { (2007) }\end{array}$ \\
\hline CRTs & Barium, Lead & $\begin{array}{l}\text {-Contaminate underground } \\
\text { water sources on mixing } \\
\text { when leaked from shale gas } \\
\text { wells. } \\
\text {-Ba is long term stable in the } \\
\text { environment. } \\
\text {-Lead from anthropogenic } \\
\text { sources enters in the soil } \\
\text { and water therefore, causes } \\
\text { soil, water pollution. }\end{array}$ & $\begin{array}{l}\text {-High blood } \\
\text { pressure. } \\
\text {-Respiratory } \\
\text { problems. } \\
\text {-Cardiovascular and } \\
\text { kidney disease. } \\
\text {-Behavioral changes. } \\
\text {-Altered metabolism. } \\
\text {-Neurological and } \\
\text { mental illness. } \\
\text {-Anemia. } \\
\text {-Nervous system } \\
\text { disorders in babies, } \\
\text {-Abnormal enzymatic } \\
\text { system of the body. }\end{array}$ & $\begin{array}{l}\text { Kravchenko } \\
\text { et al. (2014); } \\
\text { Lecler et al., } \\
\text { (2015); Wani } \\
\text { (2015); Xu et } \\
\text { al. (2013) }\end{array}$ \\
\hline $\begin{array}{l}\text { Plastic of Key- } \\
\text { boards, Monitors } \\
\text { etc. }\end{array}$ & $\begin{array}{l}\text { Brominated } \\
\text { dioxins and } \\
\text { Hydrocarbons }\end{array}$ & $\begin{array}{l}\text {-Brominated dioxins are } \\
\text { highly persistent } \\
\text { environmental pollutants. } \\
\text {-Increases total toxicity of } \\
\text { environment. } \\
\text {-Hydrocarbons contribute } \\
\text { in global warming and } \\
\text { green house effect. }\end{array}$ & $\begin{array}{l}\text {-Affect neuronal } \\
\text { development. } \\
\text {-Irregular heart beat. } \\
\text {-Coma. } \\
\text {-Prostate cancer. }\end{array}$ & $\begin{array}{l}\text { Birnbaum et } \\
\text { al. (2003); } \\
\text { Ince and } \\
\text { Ince (2019); } \\
\text { Tue et al. } \\
\text { (2013) }\end{array}$ \\
\hline Mobile battery & $\begin{array}{l}\text { Lithium and } \\
\text { Nickel }\end{array}$ & $\begin{array}{l}\text {-Lithium leaching affects } \\
\text { soil and water systems. } \\
\text {-Toxic effects of lithium } \\
\text { causes river water pollution } \\
\text { and wildlife destruction. } \\
\text {-Nickel adversely affects the } \\
\text { environment. } \\
\text {-Nickel promotes GHG } \\
\text { emissions, habitat loss and } \\
\text { air, water, soil pollution. }\end{array}$ & $\begin{array}{l}\text {-Burning sensation. } \\
\text {-Cough. } \\
\text {-Skin rashes and } \\
\text { redness. } \\
\text {-Vomiting. } \\
\text {-Abnormal lung } \\
\text { activity. } \\
\text {-Chronic bronchitis. } \\
\text {-Lung cancer. } \\
\text {-Dermatitis. }\end{array}$ & $\begin{array}{l}\text { Gaines and } \\
\text { Dunn } \\
\text { (2014); Gen- } \\
\text { chi et al. } \\
\text { (2020); } \\
\text { Hedya et al. } \\
\text { (2019); } \\
\text { Nakajima et } \\
\text { al. (2017) }\end{array}$ \\
\hline
\end{tabular}


Table 3. Continued...

\begin{tabular}{lllll}
\hline E-waste Sources & Constituents & Consequences & Health Impacts & References \\
\hline Semiconductors & Cadmium & -Highly persistent toxicant. & -Deformed brain & Dhiman \\
and Chip resistor & & -Industrial activities like & development. & $(2020) ;$ \\
& & smelting and reclamation & -Cancer. & Dökmeci et \\
& & raise cadmium concentra- & -Emphysema. & al. (2009); \\
& tion in the air. & -Chronic obstructive & Fleischer et \\
& & pulmonary disease. & al. (1974); \\
& & -Renal and & Hayat et al. \\
& & Cardiovascular ailments. & $(2019)$ \\
\hline
\end{tabular}

\section{Conclusion}

Bioleaching is a simple and exceptionally successful innovative technology for metal extraction from e-waste scrap and its scientific management. Aside from metal recovery, this technique likewise gives remedial measures to the detoxification of wastewater, mechanical waste, heavy metals, and sewage sludge. Organisms assume their significant role in the biogeochemical cycling and productive extraction of metals from electronic waste. The inclusion of organisms modifies the procedure of metal extraction when compared with the ordinary metal extraction procedures of pyro and hydrometallurgy. Nonetheless, a few confinements like inconsistent and low recovery yield, slow procedure, risk of contamination have been distinguished as the genuine problems with this process. Therefore, additional research is needed to modify the existing bioleaching process for higher metal recovery rates from electronic waste scrap.

Conflict of interest: The authors declare no conflict of interest.

\section{Acknowledgment}

The authors are thankful to the Central University of Himachal Pradesh and the Central University of Haryana for providing the necessary facilities for the writing of this article.

\section{References}

Altinkaya, P., Mäkinen, J., Kinnunen, P., Kolehmainen, E., Haapalainen, M. and Lundström, M. (2018). Effect of biological pretreatment on metal extraction from flotation tailings for chloride leaching. Minerals Engineering, 129: 47-53.

Argumedo-Delira, R., Gómez-Martínez, M.J. and Soto, B.J. (2019). Gold bioleaching from printed circuit boards of mobile phones by Aspergillus niger in a culture without agitation and with glucose as a carbon source. Metals, 9(5): 521.

Arshadi, M., Yaghmaei, S. and Esmaeili, A. (2020). Evaluating the optimal digestion method and value distribution of precious metals from different waste printed circuit boards. Journal of Material Cycles and Waste Management: 1-9.

Arya, S. and Kumar, S. (2020). Bioleaching: urban mining option to curb the menace of e-waste challenge. Bioengineered, 11(1): 640-660.

Awasthi, A.K., Zeng, X. and Li, J. (2016). Environmental pollution of electronic waste recycling in India: a critical review. 
Environmental Pollution, 211: 259-270.

Bal, B., Ghosh, S. and Das, A.P. (2019). Microbial recovery and recycling of manganese waste and their future application: a review. Geomicrobiology Journal, 36(1): 85-96.

Baniasadi, M., Graves, J.E., Ray, D.A., De Silva, A.L., Renshaw, D. and Farnaud, S. (2020). Closed-Loop Recycling of Copper from Waste Printed Circuit Boards Using Bioleaching and Electrowinning Processes. Waste and Biomass Valorization: $1-12$.

Becci, A., Karaj, D., Merli, G. and Beolchini, F. (2020). Biotechnology for Metal Recovery from End-of-Life Printed Circuit Boards with Aspergillus niger. Sustainability, 12(16): 6482.

Birnbaum, L.S., Staskal, D.F. and Diliberto, J.J. (2003). Health effects of polybrominated dibenzo-p-dioxins (PBDDs) and dibenzofurans (PBDFs). Environment International, 29(6): 855-860.

Biswal, B.K., Jadhav, U.U., Madhaiyan, M., Ji, L., Yang, E.H. and Cao, B. (2018). Biological leaching and chemical precipitation methods for recovery of $\mathrm{Co}$ and Li from spent lithium-ion batteries. ACS Sustainable Chemistry and Engineering, 6(9): 12343-12352.

Blackburn, L.S. and Solutions, I.S. (2017). Health and environmental dangers of SF6-filled switchgear. EE Publishers.

Chi, T.D., Lee, J., Pandey, B.D., Yoo, K. and Jeong, J. (2011). Bioleaching of gold and copper from waste mobile phone PCBs by using a cyanogenic bacterium. Minerals Engineering, 24(11): 1219-1222.

Dervos, C.T. and Vassiliou, P. (2000). Sulfur hexafluoride (SF6): global environmental effects and toxic byproduct formation. Journal of the Air and Waste Management Association, 50(1): 137-141.

Dhiman, V. (2020). Preliminary toxicity assessment of chromium (Cr) and lead (Pb) on terrestrial snail (Helix aspersa). Archives of Agriculture and Environmental Science, 5(1): 67-72.

Dökmeci, H., Öngen, A. and Dağdeviren, Ş. (2009). Environmental toxicity of cadmium and health effect.

Drits, V.A. and Manceau, A. (2000). A model for the mechanism of $\mathrm{Fe}^{3+}$ to $\mathrm{Fe}^{2+}$ reduction in dioctahedral smectites. Clays and Clay Minerals, 48(2): 185-195.

Fleischer, M., Sarofim, A.F., Fassett, D.W., Hammond, P., Shacklette, H.T., Nisbet, I.C. and Epstein, S. (1974). Environmental impact of cadmium: a review by the Panel on Hazardous Trace Substances. Environmental Health Perspectives, 7: $253-323$.

Forti, V., Balde, C.P., Kuehr, R. and Bel, G. (2020). The Global e-waste Monitor 2020: Quantities, flows and the circular economy potential.

Gaines, L.L. and Dunn, J.B. (2014). Lithium-ion battery environmental impacts. In Lithium-Ion Batteries, Elsevier: pp. $483-508$.

Geerlings, N., Zetsche, E.M., Hidalgo-Martinez, S., Middelburg, J.J. and Meysman, F.J.R. (2019). Mineral formation induced by cable bacteria performing long-distance electron transport in marine sediments. Biogeosciences, 16(3): 811-829.

Genchi, G., Carocci, A., Lauria, G., Sinicropi, M.S. and Catalano, A. (2020). Nickel: human health and environmental toxicology. International Journal of Environmental Research and Public Health, 17(3): 679.

Ghosh, M., Sur, D., Basu, S. and Banerjee, P.S. (2020). Metallic Materials From E-Waste, Encyclopedia of Renewable and Sustainable Materials, Elsevier.

Ha, E., Basu, N., Bose-O'Reilly, S., Dórea, J.G., McSorley, E., Sakamoto, M. and Chan, H.M. (2017). Current progress on understanding the impact of mercury on human health. Environmental Research, 152: 419-433.

Hayat, M.T., Nauman, M., Nazir, N., Ali, S. and Bangash, N. (2019). Environmental hazards of cadmium: past, present, and future. In Cadmium Toxicity and Tolerance in Plants, Elsevier: 163-183).

Hedya, S.A., Avula, A. and Swoboda, H.D. (2019). Lithium toxicity. In StatPearls [Internet]. StatPearls Publishing.

Hong, Y. and Valix, M. (2014). Bioleaching of electronic waste using acidophilic sulfur oxidising bacteria. Journal of Cleaner Production, 65: 465-472.

Ilyas, S., Anwar, M.A., Niazi, S.B. and Ghauri, M.A. (2007). Bioleaching of metals from electronic scrap by moderately thermophilic acidophilic bacteria. Hydrometallurgy, 88(1-4): 180-188. 
Ince, M. and Ince, O.K. (2019). Introductory Chapter: Sources, Health Impact, and Environment Effect of Hydrocarbons. In Hydrocarbon Pollution and its Effect on the Environment. IntechOpen.

Kaya, M. (2016). Recovery of metals from electronic waste by physical and chemical recycling processes. International Journal of Chemical, Molecular, Nuclear, Materials and Metallurgical Engineering, 10(2): 232-243.

Kim, Y.R., Harden, F.A., Toms, L.M.L. and Norman, R.E. (2014). Health consequences of exposure to brominated flame retardants: a systematic review. Chemosphere, 106: 1-19.

Kravchenko, J., Darrah, T.H., Miller, R.K., Lyerly, H.K. and Vengosh, A. (2014). A review of the health impacts of barium from natural and anthropogenic exposure. Environmental Geochemistry and Health, 36(4): 797-814.

Kumar, A., Saini, H.S. and Kumar, S. (2018). Bioleaching of gold and silver from waste printed circuit boards by Pseudomonas balearica SAE1 isolated from an e-waste recycling facility. Current Microbiology, 75(2): 194-201.

Lecler, M.T., Zimmermann, F., Silvente, E., Clerc, F., Chollot, A. and Grosjean, J. (2015). Exposure to hazardous substances in Cathode Ray Tube (CRT) recycling sites in France. Waste Management, 39: 226-235.

Li, J., Liang, C. and Ma, C. (2015). Bioleaching of gold from waste printed circuit boards by Chromobacterium violaceum. Journal of Material Cycles and Waste Management, 17(3): 529-539.

Lindqvist, O. (1995). Environmental impact of mercury and other heavy metals. Journal of Power Sources, 57(1-2): 3-7.

Liu, R., Li, J. and Ge, Z. (2016). Review on Chromobacterium violaceum for gold bioleaching from e-waste. Procedia Environmental Sciences, 31: 947-953.

Maluckov, B.S. (2017). The catalytic role of Acidithiobacillus ferrooxidans for metals extraction from mining-metallurgical resource. Biodiversity International Journal, 1(3): 109-119.

Masau, R.J.Y. (1999). The mechanism of thiosulfate oxidation by Thiobacillus thiooxidans pp. 8085.

Miao, B., Shen, L., Liu, X., Zeng, W. and Wu, X. (2020). Bioinformatics and Transcriptional Study of the Nramp Gene in the Extreme Acidophile Acidithiobacillus ferrooxidans Strain DC. Minerals, 10(6): 544.

Mihai, F.C. (2016). E-Waste in Transition: From Pollution to Resource. BoD-Books on Demand.

Nakajima, K., Nansai, K., Matsubae, K., Tomita, M., Takayanagi, W. and Nagasaka, T. (2017). Global land-use change hidden behind nickel consumption. Science of the Total Environment, 586: 730-737.

Nancharaiah, Y.V., Mohan, S.V. and Lens, P.N.L. (2016). Biological and bioelectrochemical recovery of critical and scarce metals. Trends in Biotechnology, 34(2): 137-155.

Pant, D., Giri, A. and Dhiman, V. (2018). Bioremediation techniques for e-waste Management. In Waste Bioremediation. Springer, pp. 105-125.

Pant, N.D. and Sharma, M. (2015). Urinary tract infection caused by Chromobacterium violaceum. International Journal of General Medicine, 8: 293.

Pavithra, K.G., Rajan, P.S.S., Balaji, D. and Gopinath, K.P. (2020). Sustainable Electronic-Waste Management: Implications on Environmental and Human Health. In e-waste Recycling and Management. Springer, pp. 201-218.

Saavedra, A., Aguirre, P. and Gentina, J.C. (2020). Biooxidation of iron by Acidithiobacillus ferrooxidans in the presence of D-galactose: Understanding its influence on the production of EPS and cell tolerance to high concentrations of iron. Frontiers in Microbiology, 11: 759.

Sajjad, W., Zheng, G., Din, G., Ma, X., Rafiq, M. and Xu, W. (2019). Metals extraction from sulfide ores with microorganisms: the bioleaching technology and recent developments. Transactions of the Indian Institute of Metals, 72(3): 559-579.

Sand, W., Gehrke, T., Jozsa, P.G. and Schippers, A. (2001). (Bio) chemistry of bacterial leaching-direct vs. indirect bioleaching. Hydrometallurgy, 59(2-3): 159-175.

Sarikaya, S., Karcioglu, O., Ay, D., Cetin, A., Aktas, C. and Serinken, M. (2010). Acute mercury poisoning: a case report. BMC Emergency Medicine, 10(1): 7.

Segev, O., Kushmaro, A. and Brenner, A. (2009). Environmental impact of flame retardants (persistence and biodegradability). 
International Journal of Environmental Research and Public Health, 6(2): 478-491.

Srichandan, H., Mohapatra, R.K., Singh, P.K., Mishra, S., Parhi, P.K. and Naik, K. (2020). Column bioleaching applications, process development, mechanism, parametric effect and modelling: A review. Journal of Industrial and Engineering Chemistry.

Tsai, W.T. (2007). The decomposition products of sulfur hexafluoride (SF6): Reviews of environmental and health risk analysis. Journal of Fluorine Chemistry, 128(11): 1345-1352.

Tue, N.M., Takahashi, S., Suzuki, G., Isobe, T., Viet, P.H., Kobara, Y. and Tanabe, S. (2013). Contamination of indoor dust and air by polychlorinated biphenyls and brominated flame retardants and relevance of non-dietary exposure in Vietnamese informal e-waste recycling sites. Environment International, 51: 160-167.

Vaish, B., Sharma, B., Singh, P. and Singh, R.P. (2020). e-waste and Their Implications on the Environment and Human Health. In e-waste Recycling and Management. Springer. pp. 219-232.

Valix, M. (2017). Bioleaching of electronic waste: milestones and challenges. In Current developments in biotechnology and bioengineering. Elsevier: pp. 407-442.

Wang, L., Hou, D., Cao, Y., Ok, Y.S., Tack, F.M.G., Rinklebe, J. and O'Connor, D. (2020). Remediation of mercury contaminated soil, water, and air: A review of emerging materials and innovative technologies. Environment International, 134: 105281.

Wang, S., McNamara, S.M., Moore, C.W., Obrist, D., Steffen, A., Shepson, P.B. and Pratt, K.A. (2019). Direct detection of atmospheric atomic bromine leading to mercury and ozone depletion. Proceedings of the National Academy of Sciences, 116(29): 14479-14484

Wani, A. (2015). Lead toxicity: a review. Lead Toxicity: A Review. Interdisciplinary Toxicology, 8(2): 55.

Willner, J. and Fornalczyk, A. (2013). Extraction of metals from electronic waste by bacterial leaching. Environment Protection Engineering, 39(1): 197-208.

Wu, W., Liu, X., Zhang, X., Zhu, M. and Tan, W. (2018). Bioleaching of copper from waste printed circuit boards by bacteria-free cultural supernatant of iron-sulfur-oxidizing bacteria. Bioresources and Bioprocessing, 5(1): 10.

Xu, Q., Yu, M., Kendall, A., He, W., Li, G. and Schoenung, J.M. (2013). Environmental and economic evaluation of cathode ray tube (CRT) funnel glass waste management options in the United States. Resources, Conservation and Recycling, 78: 92-104.

Yu, G., Bu, Q., Cao, Z., Du, X., Xia, J., Wu, M. and Huang, J. (2016). Brominated flame retardants (BFRs): a review on environmental contamination in China. Chemosphere, 150: 479-490.

Zhao, F. and Wang, S. (2019). Bioleaching of electronic waste using extreme acidophiles. In Electronic Waste Management and Treatment Technology. Elsevier, pp. 153-174.

Cite this chapter as: Pant, D. and Dhiman, V. (2020). An overview on environmental pollution caused by heavy metals released from e-waste and their bioleaching. In: Advances in Environmental Pollution Management: Wastewater Impacts and Treatment Technologies, Volume 1, Eds. Kumar, V., Kamboj, N., Payum, T., Singh, J. and Kumar, P., pp. 41-53, https://doi.org/10.26832/aesa-2020-aepm-04 